\title{
Clinicopathological significance of the gene expression of matrix metalloproteinase-7, insulin-like growth factor-1, insulin-like growth factor-2 and insulin-like growth factor-1 receptor in patients with colorectal cancer: Insulin-like growth factor-1 receptor gene expression is a useful predictor of liver metastasis from colorectal cancer
}

\author{
TAKASHI OSHIMA ${ }^{1}$, MAKOTO AKAIKE ${ }^{2}$, KAZUE YOSHIHARA ${ }^{1}$, MANABU SHIOZAWA $^{2}$, \\ NAOTO YAMAMOTO ${ }^{1}$, TSUTOMU SATO ${ }^{1}$, ROPPEI YAMADA ${ }^{1}$, SHOICH FUJII ${ }^{1}$, YASUSHI RINO ${ }^{3}$, \\ CHIKARA KUNISAKI ${ }^{1}$, KATSUAKI TANAKA ${ }^{1}$, MUNETAKA MASUDA ${ }^{3}$ and TOSHIO IMADA ${ }^{4}$ \\ ${ }^{1}$ Yokohama City University Medical Center, Gastroenterological Center; \\ ${ }^{2}$ Department of Surgery, Kanagawa Cancer Center; ${ }^{3}$ Department of First Surgery, \\ Yokohama City University; ${ }^{4}$ Yokohama City University, Yokohama, Japan
}

Received January 24, 2008; Accepted April 11, 2008

DOI: $10.3892 /$ or_00000015

\begin{abstract}
Matrix metalloproteinase-7 (MMP-7), secreted by cancer cells, has been implicated classically in the basement membrane destruction associated with tumor cell invasion and metastasis. Epidemiological studies have established a correlation between high levels of circulating insulin-like growth factor-1 (IGF-1) and the relative risk of colorectal cancer, which is known to produce MMP-7. We examined the clinicopathological significance of the relative expression of $M M P-7, I G F-1, I G F-2$ and $I G F-1$ receptor genes in patients with colorectal cancer, especially with regard to metastasis. We studied surgical specimens of cancer tissue and adjacent normal mucosa obtained from 205 patients with untreated colorectal carcinoma. MMP-7, IGF-1, IGF-2, IGF-1R and Bactin mRNA in cancer tissue and adjacent normal mucosa were measured by quantitative real-time reverse-transcriptase polymerase chain reaction. $M M P-7$ and $I G F-1 R$ gene expression levels were higher in cancer tissue than in adjacent normal mucosa. In contrast, $I G F-1$ gene expression was lower in cancer tissue than in adjacent normal mucosa. As for the relationship of gene expression to clinicopathological factors,
\end{abstract}

Correspondence to: Dr Takashi Oshima, Yokohama City University Medical Center, Gastroenterological Center, 4-57 Urafune-cho, Minami-ku, Yokohama-shi, Kanagawa-ken 232-0024, Japan E-mail: ohshimatakashi@yahoo.co.jp

Key words: matrix metalloproteinase-7, insulin-like growth factor-1, insulin-like growth factor-2, insulin-like growth factor-1 receptor, colorectal cancer
$I G F-1 R$ expression correlated with venous invasion and liver metastasis. $I G F-1 R$ gene expression is thus considered a useful predictor of liver metastasis from colorectal cancer.

\section{Introduction}

Colorectal cancer, one of the most prevalent cancers worldwide (1), is the second leading cause of cancer-related mortality in developed countries (2). Tumor cell invasion and metastasis involve multiple steps, including proteolytic degradation of the basement membrane (BM) and extracellular matrix (ECM), altered cell adhesion and the physical movement of tumor cells. Among the many steps of tumor invasion and metastasis, the excessive degradation of matrix is one of the hallmarks (3).

Matrix metalloproteinases (MMPs) are a key family of proteolytic enzymes involved in extracellular matrix degradation. In colorectal cancer, several MMPs have been found to be associated with tumor stage, outcomes, or both (4). MMP-7 is a member of the MMP family and, when activated, displays broad proteolytic activity against a variety of extracellular matrix substrates, including collagens, proteoglycans, elastin, laminin, fibronectin and casein (5-7). Unlike MMPs, which are synthesized by stromal cells, MMP-7 is produced exclusively by cancer cells. Miyamoto et al (8) reported that MMP-7, produced by cancer cells, regulates the bioavailability of insulin-like growth factors (IGFs) in the surrounding tissue.

IGFs have been studied extensively for possible roles in cancer growth (9-12). They are expressed ubiquitously and act as endocrine, paracrine and autocrine growth factors. Insulin-like growth factor-1 (IGF-1) is associated with an increased risk of cancer (13). Functionally, IGF-1 not only stimulates cell proliferation, but also inhibits apoptosis. The combination of these mitogenic and antiapoptotic effects is 
now recognized to have a profound impact on tumor growth (14). Previous studies have reported that IGF-2 is related to tumor progression and patient survival and that it has been suggested that IGF-2 acts as an autocrine growth factor in colorectal carcinoma (15). Insulin-like growth factor-1 receptor (IGF-1R) is the receptor of IGF-1 and IGF-2. IGF-1R overexpression promotes tumor growth, progression, invasion and metastasis (16).

In this study, we examined the clinicopathological significance of the relative expression of the $M M P-7, I G F-1$, $I G F-2$ and $I G F-1$ receptor genes in patients with colorectal cancer, especially with regard to metastasis.

\section{Materials and methods}

Patients and samples. We studied surgical specimens of cancer tissue and adjacent normal mucosa obtained from 205 patients with untreated colorectal carcinoma. The patients underwent surgery at the Yokohama City Medical Center, Gastroenterological Center and Kanagawa Cancer Center from 2002 through to 2006. Informed consent was obtained from each patient and the Yokohama City Medical Center Committee and Kanagawa Cancer Center Committee approved the study. Each tissue sample was embedded in an O.C.T. compound (Sakura Finetechnical Co., Ltd., Tokyo) and stored at $-80^{\circ} \mathrm{C}$ immediately before use. No patient had any other malignancy. After examining the histopathological features of specimens stained with hematoxylin and eosin, sections consisting of $>80 \%$ of carcinoma cells were used to prepare total RNA.

Quantitative real-time reverse-transcriptase polymerase chain reaction (PCR). Total RNA from colorectal cancer tissue and adjacent normal mucosa was prepared with the use of Trizol (Gibco, Life Tech, Gaithersburg, MD). cDNA was synthesized from $2 \mu \mathrm{g}$ of total RNA with the use of an iScript cDNA synthesis kit (Bio-Rad Laboratories, Hercules, CA). After synthesis, the cDNA was diluted at 1:4 with water and stored at $-20^{\circ} \mathrm{C}$ until use. Quantitative real-time PCR was performed with iQ SYBR-Green supermix (Bio-Rad Laboratories). PCR reactions were carried out in a total volume of $15 \mu 1$, containing cDNA derived from $75 \mathrm{ng}$ of RNA, $0.27 \mu \mathrm{M}$ of each primer, $7.5 \mu \mathrm{l}$ of iQ SYBR-Green supermix containing dATP, dCTP, dGTP and dTTP at concentrations of $400 \mu \mathrm{M}$ each and $50 \mathrm{U} / \mathrm{ml}$ of iTag DNA polymerase. The PCR consisted of $10 \mathrm{~min}$ at $94^{\circ} \mathrm{C}$ followed by 50 cycles of denaturation of the cDNA for $30 \mathrm{sec}$ at $94^{\circ} \mathrm{C}$, annealing for $30 \mathrm{sec}$ at an appropriate temperature according to Table I and a primer extension for $1 \mathrm{~min}$ at $72^{\circ} \mathrm{C}$, followed by $10 \mathrm{~min}$ at $72^{\circ} \mathrm{C}$. The PCR primer sequences of MMP-7, IGF-1, IGF-2, IGF-1R and $B$-actin, used as an internal control, are shown in Table I.

Statistical analysis. Associations of the gene expression levels of colorectal cancer with those of adjacent normal mucosa were evaluated by the Wilcoxon test. The relationship of gene expression levels to potential explanatory variables, including age, gender, tumor size, histological type, depth of invasion, lymph node metastasis, tumor location, lymphatic invasion, venous invasion and liver metastasis, were assessed with the $\chi^{2}$ test. Associations among variables were evaluated with the Mann-Whitney U test. Correlation coefficients between different variables were determined by a simple regression analysis. Statistical analyses were performed using Statview J 5.0 software (Abacus, CA). Two-sided P-values were calculated and P-values of $<0.05$ were considered to indicate a statistical significance.

\section{Results}

Comparison of MMP-7, IGF-1, IGF-2 and IGF-1R mRNA expression between colorectal cancer tissue and adjacent normal mucosa. MMP-7 and $I G F-1 R$ gene expression levels were higher in cancer tissue than in adjacent normal mucosa $(\mathrm{P}<0.001, \mathrm{P}<0.001$; Fig. $1 \mathrm{~A}$ and $\mathrm{D})$. In contrast, $I G F-1$ gene expression was lower in cancer tissue than in adjacent normal mucosa $(\mathrm{P}<0.001$; Fig. 1B). There was no significant difference between $I G F-2$ gene expression in cancer tissue and that in adjacent normal mucosa $(\mathrm{P}=0.546$; Fig. 1C).

Relationship of clinicopathological features to MMP-7, IGF-1, $I G F-2$ and IGF-1R gene expression levels. After categorizing the expression levels of $M M P-7, I G F-1, I G F-2$ and $I G F-1 R$ genes as low or high according to their respective median values, we examined the relationship between the expression levels of each gene and clinicopathological features. $M M P-7$, $I G F-1, I G F-2$ and $I G F-1 R$ gene expression levels were unrelated to age, tumor size, histological type, lymph node metastasis, tumor location and lymphatic invasion. IGF-1R gene expression levels were significantly related to venous invasion $(\mathrm{P}=0.027) . I G F-1 R$ gene expression was significantly related to liver metastasis $(\mathrm{P}=0.033)$ (Table II).

Comparison of MMP-7, IGF-1, IGF-2 and IGF-1R gene expression levels between the presence and absence of venous invasion. $I G F-1 R$ gene expression levels differed significantly between the presence and absence of venous invasion ( $\mathrm{P}=0.048)$ (Fig. 2).

Correlation among MMP-7, IGF-1, IGF-2 and IGF-1R expression. The results of the correlation analysis are shown in Fig. 3. No significant correlations were observed among the expression of these genes.

\section{Discussion}

Unlike other MMPs, which are produced by stromal cells, MMP-7 is produced by cancer cells and is implicated in the basement membrane destruction associated with cancer cell invasion and metastasis (17). IGF-1, IGF-2 and their receptor IGF-1R, participate in the development and progression of cancer (18-20). Previous studies have reported that MMP-7 produced by cancer cells regulates the bioavailability of IGFs in surrounding tissue (8).

In the present study, we examined $M M P-7, I G F-1, I G F-2$ and $I G F-1 R$ mRNA expression in colorectal cancer tissue and adjacent normal mucosa. We studied the relationship of these gene expression levels to clinicopathological features, as well as correlations among the expression of these genes. 
Table I. PCR primers and conditions.

\begin{tabular}{|c|c|c|c|}
\hline Gene & Primer & Temperature $\left({ }^{\circ} \mathrm{C}\right)$ & Product size (bp) \\
\hline$M M P-7$ & $\begin{array}{l}\text { 5'-CACTGTTCCTCCACTCCATTTAG-3' } \\
\text { 5'-CATTTATTGACATCTACCCACTGC-3' }\end{array}$ & 62.6 & 151 \\
\hline$I G F-1$ & $\begin{array}{l}\text { 5'-GTGGATGAGTGCTGCTTC-3' } \\
\text { 5'-ACTTCCTTCTGGGTCTTGG-3' }\end{array}$ & 58 & 134 \\
\hline$I G F-2$ & $\begin{array}{l}\text { 5'-TACCGCCATCTCCCTTCTC-3' } \\
\text { 5'-TCCCTCTGACTGCTCTGTG-3' }\end{array}$ & 60 & 122 \\
\hline$I G F-1 R$ & $\begin{array}{l}\text { 5'-TGCCTTGGTCTCCTTGTC-3' } \\
\text { 5'-TTTCCCTGCTTTGATGGTC-3' }\end{array}$ & 58 & 154 \\
\hline$\beta$-actin & $\begin{array}{l}\text { 5'-AGTTGCGTTACACCCTTTCTTGAC-3' } \\
\text { 5'-GCTCGCTCCAACCGACTGC-3' }\end{array}$ & 60 & 171 \\
\hline
\end{tabular}

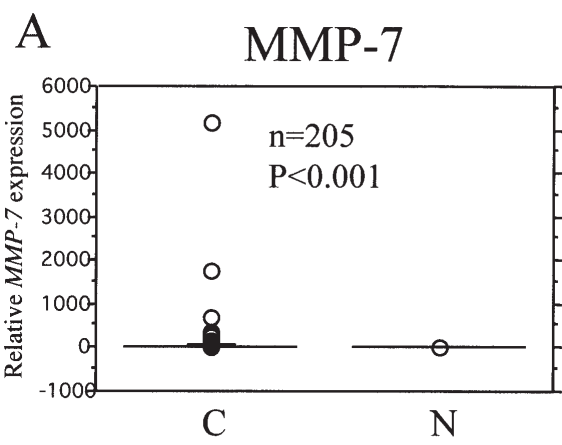

$\mathrm{C}$

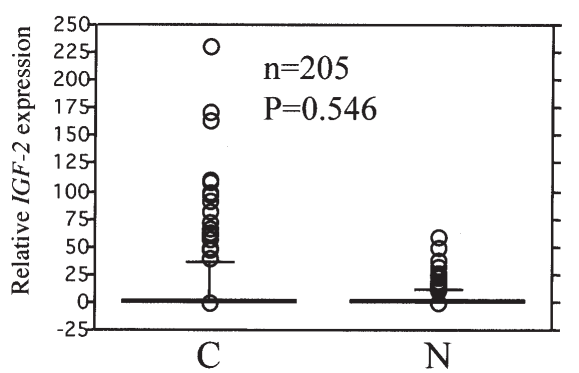

B

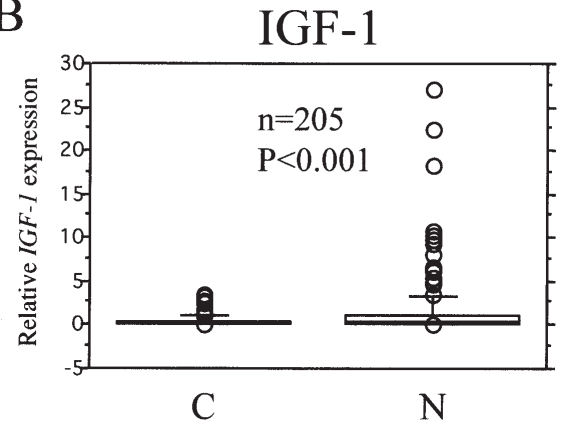

$\mathrm{D}$

IGF-1R

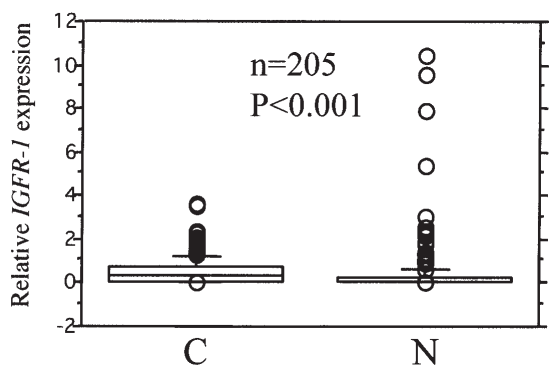

Figure 1. Comparison of $M M P-7, I G F-1, I G F-2$ and $I G F-1 R$ mRNA expression levels between colorectal cancer tissue and adjacent normal mucosa. $M M P-7$ and $I G F-1$ gene expression levels were higher in cancer tissue than in adjacent normal mucosa $(\mathrm{P}<0.001, \mathrm{P}<0.001)$. In contrast, $I G F-1$ gene expression levels were lower in cancer tissue than in adjacent normal mucosa $(\mathrm{P}<0.001)$. IGF-2 gene expression did not differ significantly between cancer tissue and adjacent normal mucosa.

Several previous studies have compared $M M P-7, I G F-1$, $I G F-2$ and $I G F-1 R$ mRNA expression levels between colorectal cancer tissue and adjacent normal mucosa. Miyata et al (17) reported that the expression of MMP-7 in tumor cells was significantly higher than that in normal cells. Freier et al (21) found that IGF-1R gene expression was higher in colorectal cancer than in adjacent normal mucosa. Nosho et al (22) showed that IGF-IR mRNA expression was detected $\sim 40 \%$ of colorectal tissues, though was undetectable in adjacent nontumor tissue. IGF-1 gene expression in colorectal cancer was reported to be higher than that in adjacent normal mucosa (21). Li et al (23) reported that the expression level of the IGF-2 gene was significantly increased in colorectal cancer as compared with that in adjacent normal mucosa. In our study, $M M P-7$ and $I G F-1 R$ gene expression levels were higher in cancer tissue than in adjacent normal mucosa. Conversely, $I G F-1$ gene expression was lower in cancer tissue than in adjacent normal mucosa. IGF-2 gene expression did not differ significantly between cancer tissue and adjacent normal mucosa.

In a study of the relationship of clinicopathological features to gene expression levels, Nosho et al (22) found that MMP-7 gene expression correlates with tumor size, location and histopathology in early colorectal carcinoma. Miyata et al (17) reported that MMP-7 expression in cancer cells correlates with an advanced pathological tumor stage. In our study, MMP-7 


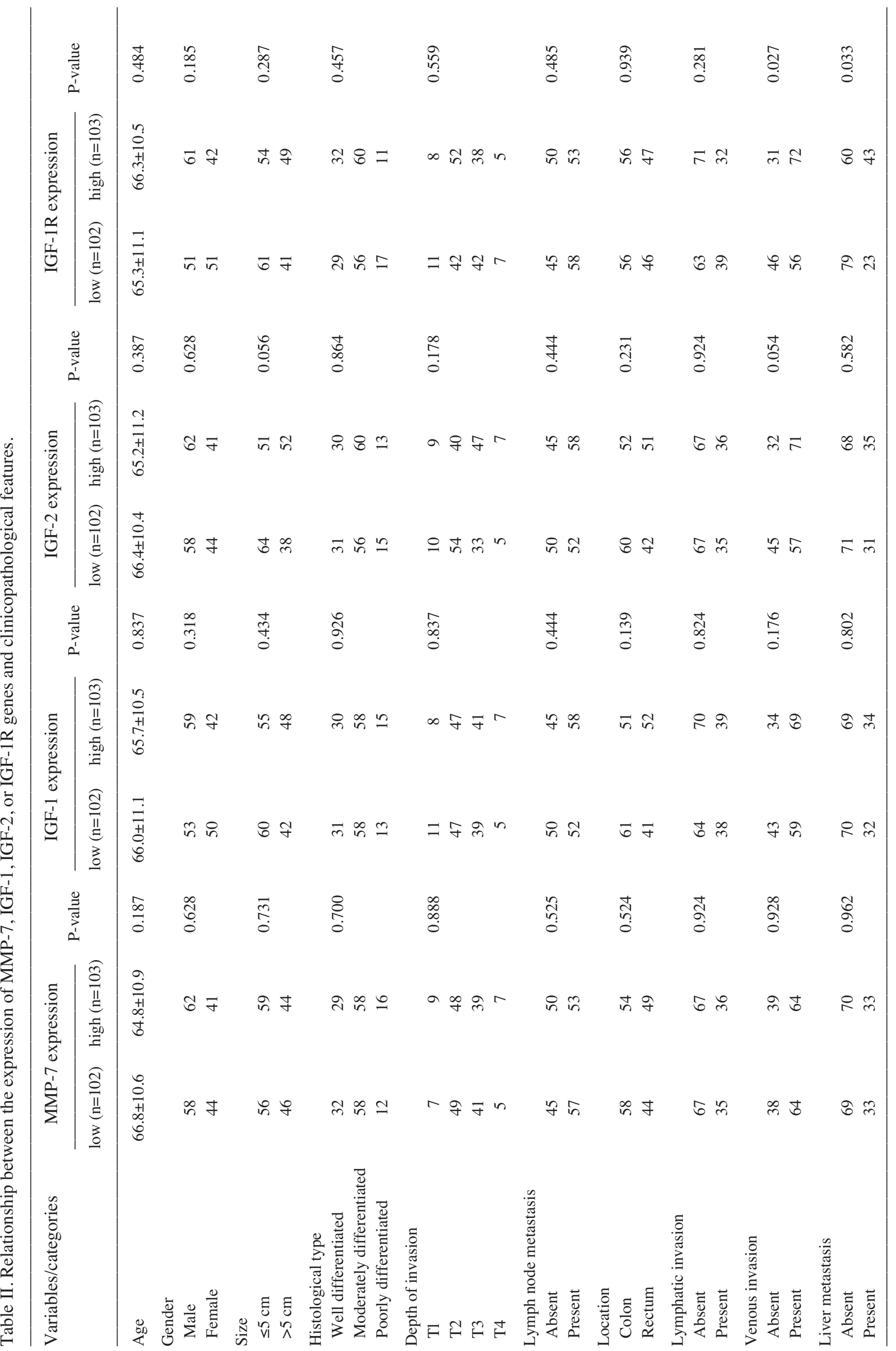



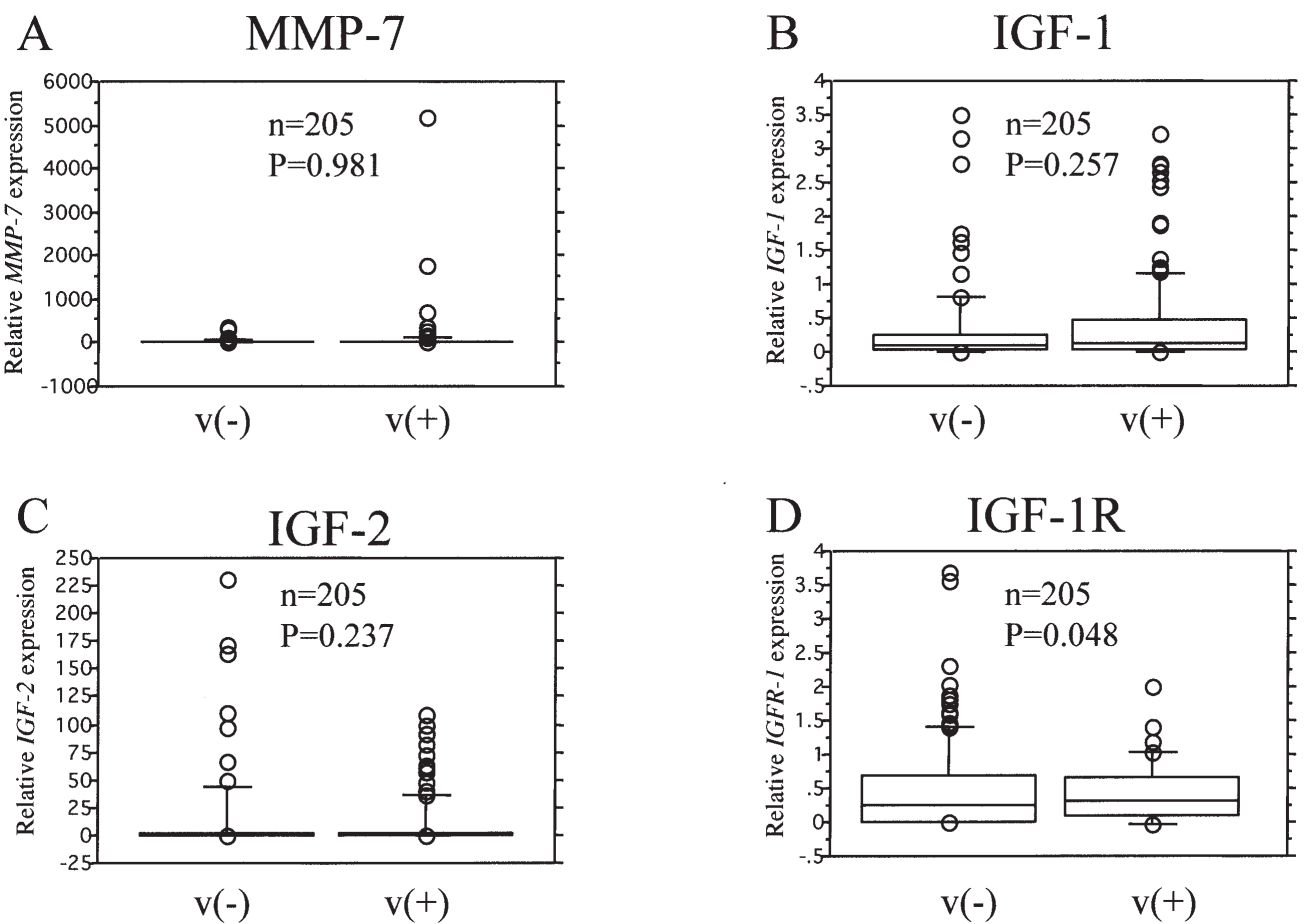

Figure 2. The association of $M M P-7, I G F-1, I G F-2$ and $I G F-1 R$ gene expression with venous invasion in 205 patients with colorectal cancer. Box boundaries, the 25 th and 75 th percentiles of the observed values; capped bars, the 10th and 90th percentiles; solid line, the median. P-values were assessed by the Mann-Whitney $U$ test. The presence or absence of venous invasion was significantly related to the gene expression levels of $I G F-1 R$.

A

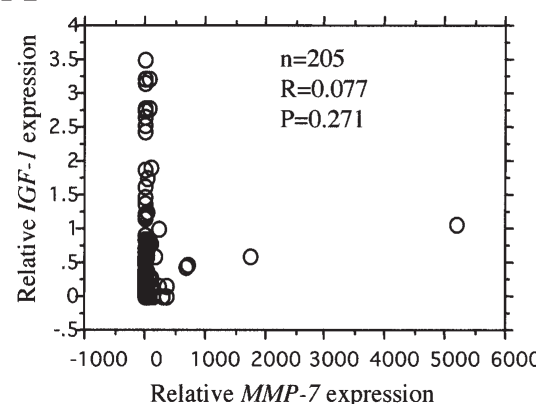

$\mathrm{D}$

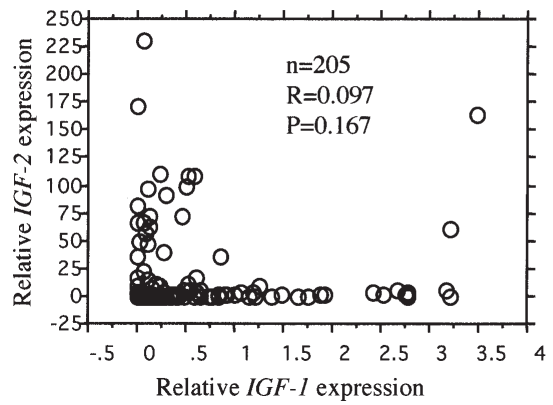

$\mathrm{B}$

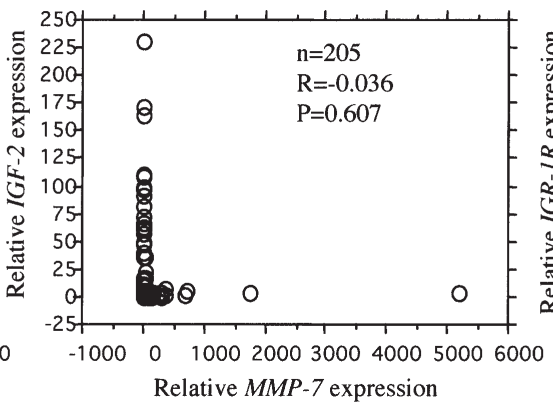

E

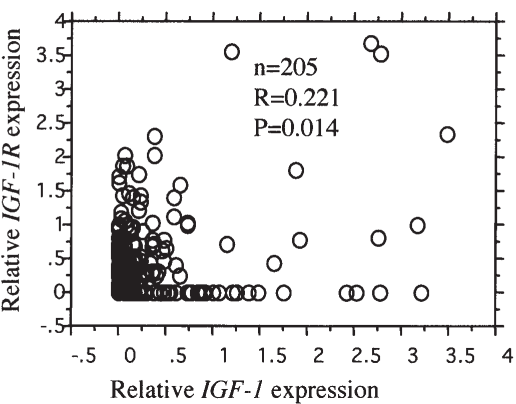

C

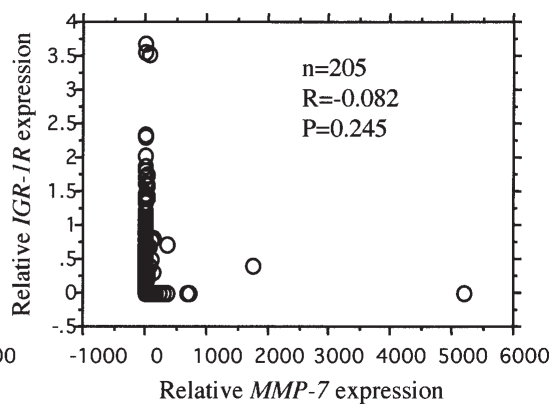

F

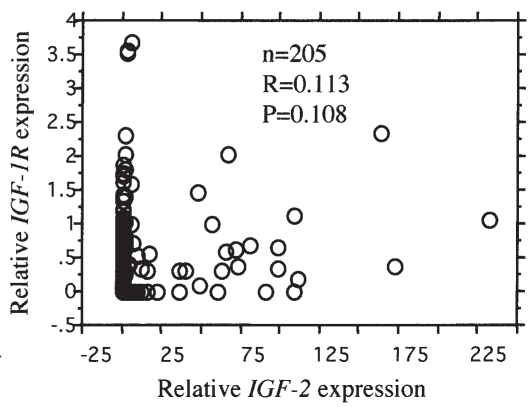

Figure 3. Correlations among gene expression levels of $M M P-7, I G F-1, I G F-2$ and $I G F-I R$ in colorectal cancers. No significant correlations were observed among the expression levels of these genes.

gene expression levels significantly correlated with gender. As for IGFs, Peters et al (24) showed that IGF-1 gene expression does not correlate with any clinicopathological characteristic. Nosho et al (22) reported that IGF-2 gene expression correlates with age and tumor size, whereas $I G F-1 R$ gene expression does not correlate with any clinicopathological characteristic in patients with early colorectal carcinoma. Mita et al (25) reported that $I G F-1 R$ gene expression does not 
correlate with any clinicopathological characteristic in prostate cancer. However, Furukawa et al (26) reported that increased postoperative tumor growth and the presence of liver metastasis were associated with significantly higher IGF-1R mRNA expression in gastrinomas. Our study found no significant correlation between $I G F-1$ or $I G F-2$ gene expression and any clinicopathological characteristic, whereas $I G F-1 R$ gene expression was significantly related to venous invasion and liver metastasis.

In a study examining interrelations among MMP-7, IGF-1, IGF-2 and IGF-1R, Miyamoto et al (8) showed that MMP-7 regulates IGF-1. Furukawa et al (26) reported a significant correlation $(\mathrm{r}=0.66, \mathrm{P}<0.0001)$ between the expression levels of the $I G F-1$ and $I G F-1 R$ genes. In our study, there were no significant correlations among these genes.

In conclusion, our study showed that $I G F-1 R$ gene expression levels were higher in adjacent normal mucosa than in cancer tissue and were significantly related to venous invasion and liver metastasis. $I G F-1 R$ gene expression is thus considered a useful predictor of liver metastasis from colorectal cancer.

\section{References}

1. Jemal A, Murray T, Ward E, Samuels A, Tiwari RC, Ghafoor A, Feuer EJ and Thun MJ: Cancer statistics. CA Cancer J Clin 55: 10-30, 2005.

2. Greenwald P: Colon cancer overview. Cancer 70: 1206-1215, 1992.

3. Liotta LA and Stetler-Stevenson WG: Tumor invasion and metastasis: an imbalance of positive and negative regulation. Cancer Res 51: 5054-5059, 1991.

4. Wagenaar-Miller RA, Gorden L and Matrisian LM: Matrix metalloproteinases in colorectal cancer: is it worth talking about? Cancer Metastasis Rev 23: 119-135, 2004.

5. Woessner JF Jr and Taplin CJ: Purification and properties of a small latent matrix metalloproteinase of the rat uterus. J Biol Chem 263: 16918-16925, 1988.

6. Miyazaki K, Hattori Y, Umenishi F, Yasumitsu H and Umeda M: Purification and characterization of extracellular matrixdegrading metalloproteinase, matrin (pump-1), secreted from human rectal carcinoma cell line. Cancer Res 50: 7758-7764, 1990.

7. Wilson CL and Matrisian LM: Matrilysin: an epithelial matrix metalloproteinase with potentially novel functions. Int J Biochem Cell Biol 28: 123-136, 1996.

8. Miyamoto S, Yano K, Sugimoto S, Ishii G, Hasebe T, Endoh Y, Kodama K, Goya M, Chiba T and Ochiai A: Matrix metalloproteinase-7 facilitates insulin-like growth factor bioavailability through its proteinase activity on insulin-like growth factor binding protein 3. Cancer Res 64: 665-671, 2004.

9. Grimberg A and Cohen P: Role of insulin-like growth factors and their binding proteins in growth control and carcinogenesis. J Cell Physiol 183: 1-9, 2000.

10. $\mathrm{Yu} \mathrm{H}$ and Rohan T: Role of the insulin-like growth factor family in cancer development and progression. J Natl Cancer Inst 92: 1472-1489, 2000.
11. Fürstenberger G and Senn HJ: Insulin-like growth factors and cancer. Lancet Oncol 3: 298-302, 2002.

12. Sandhu MS, Dunger DB and Giovannucci EL: Insulin, insulin-like growth factor-I (IGF-I), IGF binding proteins, their biologic interactions, and colorectal cancer. J Natl Cancer Inst 94: 972-980, 2002.

13. Ma J, Pollak MN, Giovannucci E, Chan JM, Tao Y, Hennekens $\mathrm{CH}$ and Stampfer MJ: Prospective study of colorectal cancer risk in men and plasma levels of insulin-like growth factor (IGF)-I and IGF-binding protein-3. J Natl Cancer Inst 91: 620-625, 1999.

14. Cory S, Vaux DL, Strasser A, Harris AW and Adams JM: Insights from Bcl-2 and Myc: malignancy involves abrogation of apoptosis as well as sustained proliferation. Cancer Res 59: $1685-1692,1999$.

15. Kawamoto K, Onodera H, Kondo S, Kan S, Ikeuchi D, Maetani S and Imamura M: Expression of insulin-like growth factor-2 can predict the prognosis of human colorectal cancer patients: correlation with tumor progression, proliferative activity and survival. Oncology 55: 242-248, 1998.

16. Foulstone E, Prince S, Zaccheo O, Burns JL, Harper J, Jacobs C, Church D and Hassan AB: Insulin-like growth factor ligands, receptors, and binding proteins in cancer. J Pathol 205: 145-153, 2005.

17. Miyata $Y$, Iwata $T$, Ohba K, Kanda S, Nishikido M and Kanetake H: Expression of matrix metalloproteinase-7 on cancer cells and tissue endothelial cells in renal cell carcinoma: prognostic implications and clinical significance for invasion and metastasis. Clin Cancer Res 12: 6998-7003, 2006.

18. Baserga R: The contradictions of the insulin-like growth factor 1 receptor. Oncogene 19: 5574-5581, 2000.

19. Wang Y and Sun Y: Insulin-like growth factor receptor-1 as an anti-cancer target: blocking transformation and inducing apoptosis. Curr Cancer Drug Targets 2: 191-207, 2002.

20. Wang Z, Ruan YB, Guan Y and Liu SH: Expression of IGF-II in early experimental hepatocellular carcinomas and its significance in early diagnosis. World J Gastroenterol 9: 267-270, 2003.

21. Freier S, Weiss O, Eran M, Flyvbjerg A, Dahan R, Nephesh I, Safra T, Shiloni E and Raz I: Expression of the insulin-like growth factors and their receptors in adenocarcinoma of the colon. Gut 44: 704-708, 1999.

22. Nosho K, Yamamoto H, Taniguchi H, Adachi Y, Yoshida Y, Arimura Y, Endo T, Hinoda Y and Imai K: Interplay of insulinlike growth factor-II, insulin-like growth factor-I, insulin-like growth factor-I receptor, COX-2, and matrix metalloproteinase-7, play key roles in the early stage of colorectal carcinogenesis. Clin Cancer Res 10: 7950-7957, 2004.

23. Li SR, Ng CF, Banerjea A, Ảhmed S, Hands R, Powar M, Ogunkolade W, Dorudi S and Bustin SA: Differential expression patterns of the insulin-like growth factor 2 gene in human colorectal cancer. Tumour Biol 25: 62-68, 2004.

24. Peters G, Gongoll S, Langner C, Mengel M, Piso P, Klempnauer J, Rüschoff J, Kreipe $\mathrm{H}$ and von Wasielewski R: IGF-1R, IGF-1 and IGF-2 expression as potential prognostic and predictive markers in colorectal-cancer. Virchows Arch 443: 139-145, 2003.

25. Mita K, Nakahara M and Usui T: Expression of the insulin-like growth factor system and cancer progression in hormone-treated prostate cancer patients. Int J Urol 7: 321-329, 2000.

26. Furukawa M, Raffeld M, Mateo C, Sakamoto A, Moody TW, Ito T, Venzon DJ, Serrano J and Jensen RT: Increased expression of insulin-like growth factor I and/or its receptor in gastrinomas is associated with low curability, increased growth, and development of metastases. Clin Cancer Res 11: 3233-3242, 2005. 